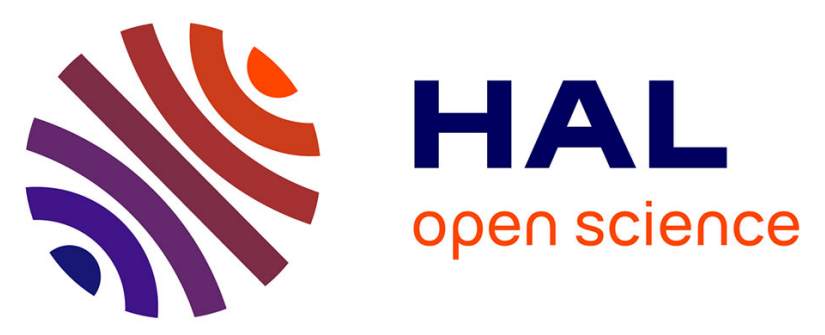

\title{
Light-induced reactivation of O2-tolerant membrane-bound [Ni-Fe] hydrogenase from the hyperthermophilic bacterium Aquifex aeolicus under turnover conditions.
}

\author{
Alexandre Ciaccafava, Cyrille Hamon, Pascale Infossi, Valérie Marchi, \\ Marie-Thérèse Giudici-Orticoni, Elisabeth Lojou
}

\section{To cite this version:}

Alexandre Ciaccafava, Cyrille Hamon, Pascale Infossi, Valérie Marchi, Marie-Thérèse Giudici-Orticoni, et al.. Light-induced reactivation of $\mathrm{O} 2$-tolerant membrane-bound [Ni-Fe] hydrogenase from the hyperthermophilic bacterium Aquifex aeolicus under turnover conditions.. Physical Chemistry Chemical Physics, 2013, 15 (39), pp.16463-16467. 10.1039/c3cp52596a . hal-00860457

\section{HAL Id: hal-00860457}

\section{https://hal-univ-rennes1.archives-ouvertes.fr/hal-00860457}

Submitted on 10 Sep 2013

HAL is a multi-disciplinary open access archive for the deposit and dissemination of scientific research documents, whether they are published or not. The documents may come from teaching and research institutions in France or abroad, or from public or private research centers.
L'archive ouverte pluridisciplinaire HAL, est destinée au dépôt et à la diffusion de documents scientifiques de niveau recherche, publiés ou non, émanant des établissements d'enseignement et de recherche français ou étrangers, des laboratoires publics ou privés. 


\title{
Light-induced reactivation of $\mathrm{O}_{2}$-tolerant membrane-bound [Ni-Fe] hydrogenase from the hyperthermophilic bacterium Aquifex aeolicus under turnover conditions
}

\author{
Alexandre Ciaccafava ${ }^{a}$, Cyrille Hamon $^{b}$, Pascale Infossi ${ }^{a}$, Valérie Marchi ${ }^{b}$, Marie-Thérèse Giudici- \\ Orticoni $^{a}$ and Elisabeth Lojou ${ }^{a}$ \\ ${ }^{a}$ Bioénergétique et Ingénierie des Protéines, Institut de Microbiologie de la Méditerranée - CNRS-AMU, 31 Chemin Aiguier, 13009 Marseille, France. \\ Fax: 33 (0) 4911640 97; Tel: 33 (0) 4911645 24; E-mail: lojou@imm.cnrs.fr \\ ${ }^{b}$ Université Rennes 1, Institut des Sciences Chimiques de Rennes, CNRS UMR 6226 Campus de Beaulieu, 35042 Rennes, France \\ $10 \dagger$ Electronic Supplementary Information (ESI) available. See DOI: 10.1039/b000000x/
}

Received 21 Jun 2013, Accepted 12 Aug 2013

DOI: $10.1039 / \mathbf{c} 3 \operatorname{cp52596a}$

We report the effect of UV-Vis light on the membrane-bound [Ni-Fe] hydrogenase from Aquifex aeolicus under turnover ${ }_{15}$ conditions. Using electrochemistry, we show a potential dependant light sensitivity and propose that a light-induced structural change of the $[\mathrm{Ni}-\mathrm{Fe}]$ active site is related to an enhanced reactivation of the hydrogenase under illumination at high potentials.

\section{Introduction}

Hydrogenases are metallo-enzymes that catalyze the hydrogen interconversion into protons and electrons according to the reaction $\mathrm{H}_{2} \leftrightarrow$ $2 \mathrm{H}^{+}+2 \mathrm{e}^{-1}$. They are classified in three distinct classes according to the metal content of their active site either [Fe], [Fe-Fe] or $[\mathrm{Ni}-\mathrm{Fe}]{ }^{2}$. ${ }_{20}$ While $[\mathrm{Fe}]$ and $[\mathrm{Fe}-\mathrm{Fe}]$ hydrogenases suffer a dramatic irreversible degradation under $\mathrm{O}_{2}{ }^{3,4},[\mathrm{Ni}-\mathrm{Fe}]$ hydrogenases are generally reversibly inhibited under aerobic conditions ${ }^{5}$. For various $[\mathrm{Ni}-\mathrm{Fe}]$ hydrogenases, activation/inactivation process and the different associated states of the active site have been deeply studied using EPR and FTIR spectroscopies (see ESI $1{ }^{\dagger}{ }^{6-9}$. Under aerobic/oxidative conditions the [Ni-Fe] active site is interconverted into a mixture of two inactive states, so-called Ni-A "Unready" and $\mathrm{Ni}-\mathrm{B}$ "Ready" ${ }^{7}{ }^{10}$. While Ni-B is readily activated under $\mathrm{H}_{2}$ or reducing conditions ${ }^{11}$, Ni-A requires a longer time. The nature of the 25 oxygenic ligand bridging the hetero-binuclear active site accounts for this difference in kinetics of reactivation ${ }^{12-14}$. The Ni-B state bears a hydroxo $\left(\mathrm{OH}^{-}\right)$ligand whereas the nature of the oxygenic ligand in the Ni-A state is still a matter of debate ${ }^{15,16}$.

Recently, a subgroup of [Ni-Fe] hydrogenases able to oxidize $\mathrm{H}_{2}$ under aerobic conditions has been identified and consequently named oxygen tolerant $\left(\mathrm{O}_{2}\right.$-tolerant $)$ hydrogenases ${ }^{17}$. [Ni-Fe] hydrogenases from the hyperthermophilic bacterium Aquifex aeolicus,

Knallgas bacterium Ralstonia eutropha, enterobacterium Escherichia coli and the marine bacterium Hydrogenovibrio marinus are the 30 most currently characterized members of this subgroup ${ }^{18-23} \cdot \mathrm{O}_{2}$-tolerant hydrogenases present several properties that distinguish them from oxygen sensitive $\left(\mathrm{O}_{2}\right.$-sensitive) ones. Under oxidative conditions, $\mathrm{O}_{2}$-tolerant hydrogenases form only the Ni-B state with kinetics of reactivation 2 orders of magnitude faster than $\mathrm{O}_{2}$-sensitive hydrogenases ${ }^{8,24}$. The structural determinants of oxygen tolerance have been unraveled very recently ${ }^{25-27}$. The overall structural shape consisting of large subunit baring the [Ni-Fe] active site and a small subunit harboring 3 iron-sulfur clusters, aligned as a conductive electronic wire, is very similar to $\mathrm{O}_{2}$-sensitive hydrogenases. However, a 35 peculiar [3Fe-4S] cluster proximal to the active site coordinated by 6 cysteines has been observed instead of the proximal [4Fe-4S] cluster coordinated by 4 cysteines classically observed in $\mathrm{O}_{2}$-sensitive hydrogenases ${ }^{28}$. It is thought to be the key feature of the oxygen tolerance enabling the fast reduction of $\mathrm{O}_{2}$ to water ${ }^{29}$. These enzymes have stimulated the curiosity of the community since biotechnological applications relying on aerobic hydrogen oxidation, could be envisioned with more sustainability. Recently, $\mathrm{H}_{2} / \mathrm{O}_{2}$ biofuel cells based on this subgroup of hydrogenases have been reported, delivering more than $1 \mathrm{~mW} . \mathrm{cm}^{-2}{ }^{30-32}$. It was however

40 demonstrated that the anaerobic formation of the inactive Ni-B state at high potential was responsible for a decrease of the biofuel cell performances.

From literature survey, it appears that irradiation of the active site could provide tools to overcome this limitation. Some of the inactive states of [Ni-Fe] hydrogenases have been studied by spectroscopy under illumination (see ESI $1 \dagger$ ). The oxygenic ligand in the $\mathrm{Ni}$-A inactive state in $\mathrm{O}_{2}$-sensitive hydrogenases, has been shown to slightly change its binding configuration upon irradiation. It 45 switches from a bridging position coordinated by both the iron and nickel atoms to a coordination where the Fe-O bond is cleaved ${ }^{33}$. The $\mathrm{Ni}$-SIr state, an intermediate between the inactive Ni-B state and the most oxidized Ni-SIa active state has been shown to be light sensitive, yielding to the Ni-SL state ${ }^{34}$. Irradiation of the active site leads to a cleavage of the bond between the Fe atom and the hydroxo bridging ligand. Moreover, the CO-inhibited states (Ni-CO and Ni-SCO) have been reported to undergone photoreactivation ${ }^{35,36}$.

We report in this work the effect of illumination under turnover conditions on the reactivation at high potential of the ${ }_{50}$ hyperthermophilic membrane-bound [Ni-Fe] hydrogenase from Aquifex aeolicus (MbH1). Using cyclic voltammetry (CV) and chronoamperometry (CA), we show that photosensitivity of $\mathrm{MbH} 1$ depends on both potential and light intensity. We propose this lightinduced process to be related to the conversion of the inactive Ni-B state to an active form. 


\section{Experimental}

$\mathrm{CV}$ and CA were done using a $\mu$ Autolab type III potentiostat from Autolab. A conventional three-electrode system was used with an $\mathrm{Ag} / \mathrm{AgCl} / \mathrm{NaCl}$ (sat.) reference electrode, and a gold wire as auxiliary electrode. All potentials were quoted against the $\mathrm{Ag} / \mathrm{AgCl}$ reference. Prior to each experiment, the solutions were deoxygenated by bubbling with high-purity nitrogen or hydrogen.

${ }_{5}$ Double glass layer electrochemical cell was thermo-regulated with a water bath. The reference electrode was separated from the warmed electrolyte using a side junction maintained at room temperature. The current are the average of at least three replicates and have been normalized with the highest catalytic current.

The graphite working electrode was constructed from $3 \mathrm{~mm}$ rods of pyrolytic graphite (PG) inserted in Peek polymer casings from Bio-Logic SAS. The PG electrode was carefully polished with alumina 0.04 $\mu \mathrm{m}$ (PRESI). $2 \mu \mathrm{L}$ of MbH1 $4 \mu \mathrm{M}$ (purified as described in ${ }^{30}$ ) 10 were adsorbed on the PG electrode. Electrochemical experiments were performed in $50 \mathrm{mM}$ Hepes buffer pH 7.2 at $60^{\circ} \mathrm{C}$.

Illumination at $405 \mathrm{~nm}$ of the PG electrode was achieved by placing a LED (M405L2 from Thorlabs) triggered by a potentiometer (LEDD1B from Thorlabs) at $1 \mathrm{~cm}$ of the working PG electrode. The intensity of illumination $\left(\mathrm{E}_{\mathrm{V}}\right)$ of the PG electrode has been measured in lux (lx) with Lux meter DX-100 (INS).

\section{${ }_{15}$ Results and discussion}

\section{MbH1 anaerobic inactivation process}

When immobilized on a PG electrode under $\mathrm{H}_{2}$ atm., MbH1 starts oxidizing $\mathrm{H}_{2}$ at $-0.55 \mathrm{~V}$. The catalytic current reaches a maximum value at a potential close to $-0.3 \mathrm{~V}$ (Fig. $1 \mathrm{~A}$ ). At more oxidizing potentials, $\mathrm{H}_{2}$ oxidation activity decreases dramatically. As already reported, $\mathrm{MbH} 1$ suffers an anaerobic inactivation process, corresponding to the interconversion between the active state to the $\mathrm{Ni}-\mathrm{B}$

20 inactive form. This phenomenon has been reported for all the $\mathrm{O}_{2}$-tolerant $[\mathrm{Ni}-\mathrm{Fe}]$ hydrogenases electrochemically characterized. This inactivation process can be highlighted by chronoamperometric experiments. From $-0.5 \mathrm{~V}$ to $-0.3 \mathrm{~V}$ the low electrocatalytic signal for $\mathrm{H}_{2}$ oxidation remains stable. However, when the potential rises above $-0.3 \mathrm{~V}$ the catalytic activity decreases with time. The highest the potential, the more pronounced the decrease in current (Fig. 1B). Actually, the apparent rate of interconversion between the active and the inactive forms of $\mathrm{MbH} 1$ is potential dependant as clearly shown by the curves between $-0.2 \mathrm{~V}$ and $0 \mathrm{~V}$. Notably, it has been 25 demonstrated that while the constant of inactivation is potential independent, the constant of activation decreases exponentially as the potential rises to oxidizing values until reaching a constant value above $0 \mathrm{~V}^{24}$.
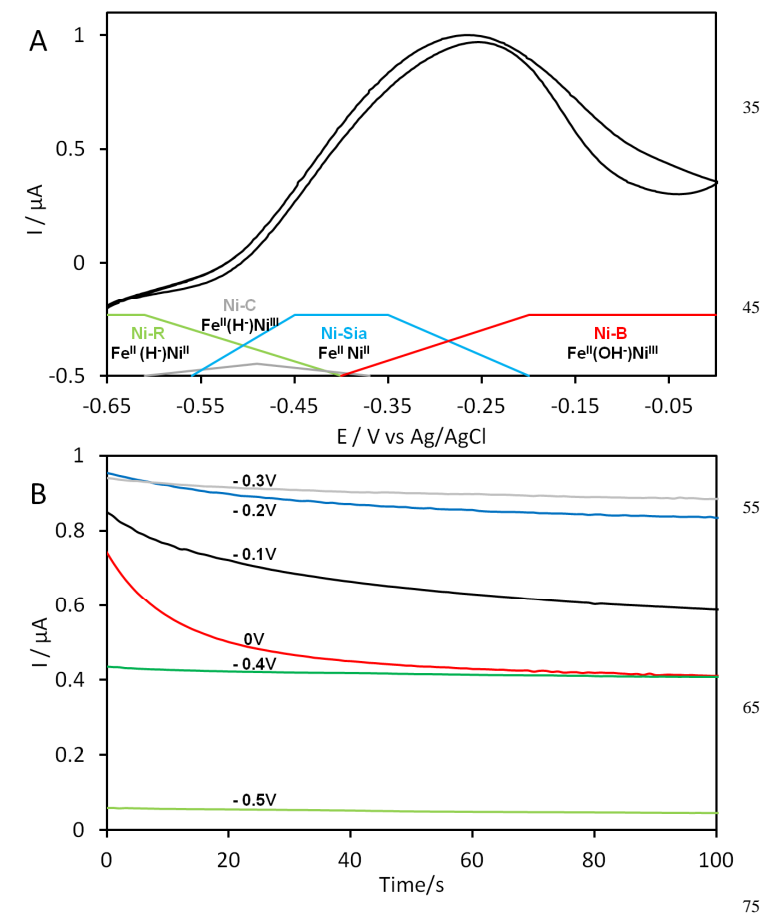

Fig. 1 (A) $\mathrm{H}_{2}$ oxidation by $\mathrm{MbH} 1$ adsorbed on a $\mathrm{PG}$ electrode followed by $\mathrm{CV}$. Schematic view of the different states of the [Ni-Fe] active site as a function of the potential are adapted from ref ${ }^{8}$. Scan rate: $5 \mathrm{mV} . \mathrm{s}^{-1}$. (B) Effect of the potential on $\mathrm{H}_{2}$ oxidation followed by CA: $-0.5 \mathrm{~V}$ (light green), $-0.4 \mathrm{~V}$ (green), $-0.3 \mathrm{~V}$ (grey), $-0.2 \mathrm{~V}$ (blue), $-0.1 \mathrm{~V}$ (black), $0 \mathrm{~V}$ (red). CA and CV were done in $50 \mathrm{mM} \mathrm{HEPES}, \mathrm{pH} 7.2,60^{\circ} \mathrm{C}, \mathrm{H}_{2}$ atm, under darkness. 


\section{Photoreactivation of MbH1}

In order to investigate the putative photosensitivity of $\mathrm{MbH} 1$ under turnover conditions, $\mathrm{CA}$ experiments have been realized under irradiation sequences of 120 s followed by a relaxation time under darkness (see ESI $2 \dagger$ ). Fig. $2 \mathrm{~A}$ shows the typical currents recorded during illumination/darkness steps. For each potential ranging from $-0.5 \mathrm{~V}$ to $0 \mathrm{~V}$, positive photocurrents differing in magnitude are 5 recorded under illumination. Control experiments on the bare PG electrode illuminated under $\mathrm{H}_{2}$ (Fig. 2B) exhibit poor photocurrent intensities for each potential, ensuring a true catalytic dependence of the photocurrents observed with MbH1. Relative to catalytic currents for $\mathrm{MbH} 1$ obtained without illumination, catalytic currents observed under irradiation are higher, whatever the potential. However a spectacular potential dependence of the photocurrent intensities is observed which does not follow the same potential dependence profile as the catalytic current obtained without illumination. As described before, the catalytic current for $\mathrm{H}_{2}$ oxidation 10 without irradiation starts decreasing above $-0.3 \mathrm{~V}$. In contrast, the catalytic current keeps increasing until $-0.1 \mathrm{~V}$ under illumination. Moreover, from $-0.5 \mathrm{~V}$ to $-0.3 \mathrm{~V}$ photocurrents represent an average of less than $5 \%$ of the catalytic current obtained under dark conditions. But, for higher potentials, sharp increases in photocurrent are observed depending on the potential (increase of $19 \%$, $45 \%$ and $39 \%$ at $-0.2 \mathrm{~V},-0.1 \mathrm{~V}$ and $0 \mathrm{~V}$ respectively). The variation of the percentage of photocurrent with potential can be rationalized by taking into account the equilibrium between the active/inactive forms of the enzyme that is displaced toward the inactive Ni-B state as 15 the driving force increases. The midpoint potential for the transition
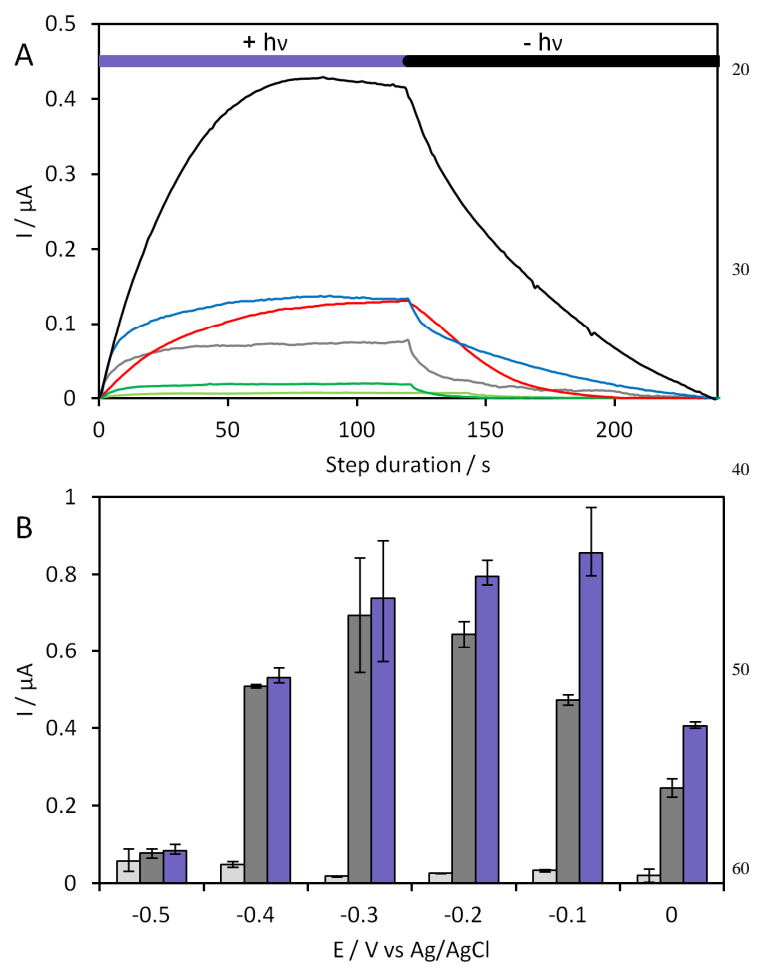

Fig. 2 (A) Light induced photocurrents and relaxation currents for $\mathrm{H}_{2}$ oxidation by $\mathrm{MbH} 1$ adsorbed on a $\mathrm{PG}$ electrode followed by $\mathrm{CA}$, $-0.5 \mathrm{~V}$ (light green), $-0.4 \mathrm{~V}$ (green), $-0.3 \mathrm{~V}$ (grey), $-0.2 \mathrm{~V}$ (blue), $-0.1 \mathrm{~V}$ (black), $0 \mathrm{~V}$ (red). (B) Catalytic currents for $\mathrm{H}_{2}$ oxidation by $\mathrm{MbH}$ obtained under illumination (purple). Catalytic currents obtained under darkness after $120 \mathrm{~s}$ of potential application (same protocol as in Fig1.B) are depicted in grey. As a control, currents obtained for illuminated bare $\mathrm{PG}$ are depicted in light grey. $50 \mathrm{mM}$ HEPES, pH 7.2, $60^{\circ} \mathrm{C}, \mathrm{H}_{2}$ atm, intensity of illumination $\mathrm{E}_{\mathrm{v}}=1500 \mathrm{~lx}$.

from the Ni-SIa active state to the Ni-B inactive state has been titrated at $-0.3 \mathrm{~V}^{8}$. Intriguingly, the divergence in photocurrent intensities is observed at the same potential of $-0.3 \mathrm{~V}$. Electrochemical experiments thus strongly suggest a light-induced reactivation process of the $\mathrm{Ni}-\mathrm{B}$ inactive form of $\mathrm{MbH} 1$.

\section{Influence of the light intensity}

To get more insight in the reactivation process involved at high oxidizing potentials, the influence of the light intensity on the photocurrent response was investigated (Fig. 3). For potentials below $-0.3 \mathrm{~V}$ where the enzyme is fully active, photocurrents of low magnitude evolve linearly with the light intensity. For highest oxidizing potentials, the magnitude of photocurrents as a function of the 80 potential follows the same profile described in Fig. 2. The photocurrents rapidly reach a maximum value with the light intensity. This suggests the formation of a species at high potential which is highly light sensitive, and reinforces the divergence in light sensitivity for active/inactive states depending on the potential. The decrease in photocurrent at the highest light intensity may be due to an irreversible 
photodegradation already reported for $\mathrm{Ni}$ - $\mathrm{B}$ states of $\mathrm{O}_{2}$-sensitive hydrogenase ${ }^{34}$.

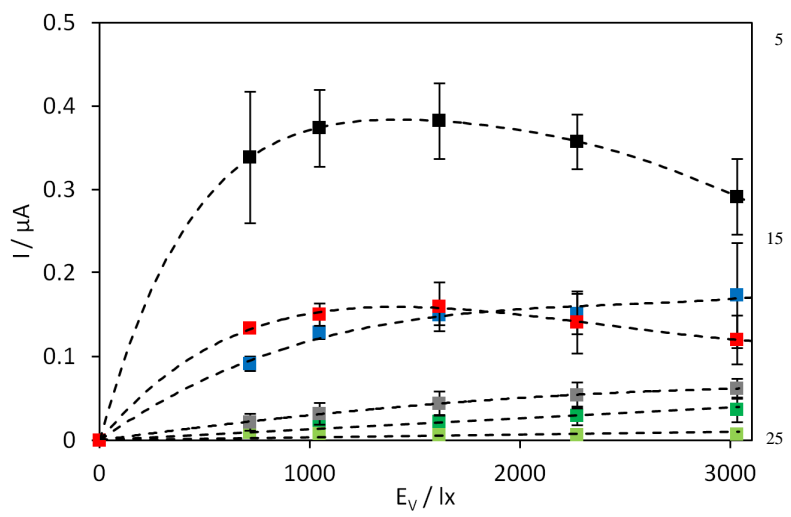

Fig. 3 Effect of the illumination intensity on the light-induced photocurrents for $\mathrm{H}_{2}$ oxidation by MbH1 adsorbed on a PG electrode followed by CA, $0.5 \mathrm{~V}$ (light green), $-0.4 \mathrm{~V}$ (green), $-0.3 \mathrm{~V}$ (grey), $-0.2 \mathrm{~V}$ (blue), $-0.1 \mathrm{~V}$ (black), $0 \mathrm{~V}$ (red). $50 \mathrm{mM} \mathrm{HEPES}, \mathrm{pH} 7.2,60^{\circ} \mathrm{C}, \mathrm{H}_{2}$ atm.

\section{Kinetics of reactivation}

35 The kinetics to reach the maximum value of the photocurrent during an illumination step can be related to the rate of reactivation. As seen in Fig. 4, it is potential and light intensity dependent. Again, a marked divergence is pointed out at the midpoint potential between active Ni-SIa and inactive Ni-B states. For potentials below $-0.3 \mathrm{~V}$, the gain in catalytic activity rapidly reaches a plateau in a mean time of $30 \mathrm{~s}$ with no net dependence on the light intensity. As potentials increase above $-0.3 \mathrm{~V}$, two major observations can be done. Firstly, the duration to reach the maximum value of the photocurrent considerably increases. Again, this correlates with the enzyme becoming

40 harder to reactivate due to the displacement of the active/inactive form equilibrium toward the inactive form ${ }^{24}$. Secondly, lower durations of reactivation are induced by increasing illumination intensities. This latter result suggests kinetics of enzyme reactivation dependant on the light intensity, and supports the hypothesis of a light-induced reactivation of the hydrogenase active site.

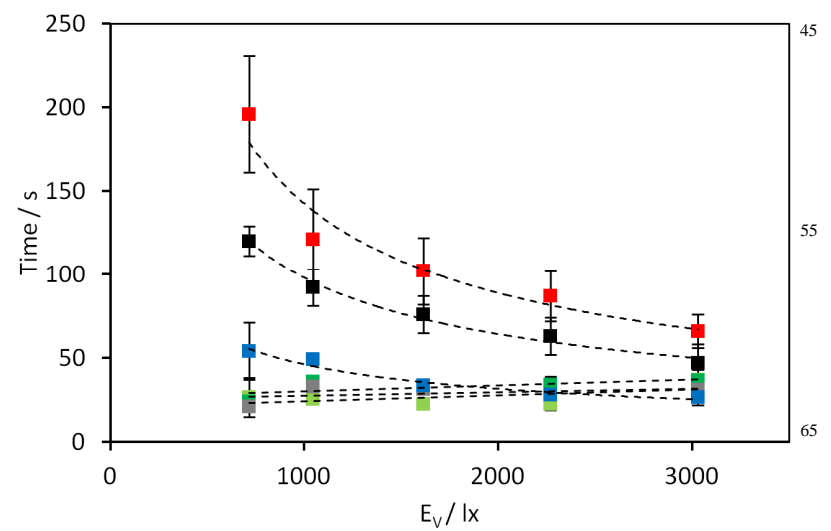

Fig. 4 Time dependence on illumination intensity to reach the maximum value of the photocurrent for $\mathrm{H}_{2}$ oxidation by $\mathrm{MbH} 1$ adsorbed on a $\mathrm{PG}$ electrode followed by CA, $-0.5 \mathrm{~V}$ (light green), $-0.4 \mathrm{~V}$ (green), $-0.3 \mathrm{~V}$ (grey), $-0.2 \mathrm{~V}$ (blue), $-0.1 \mathrm{~V}$ (black), $0 \mathrm{~V}$ (red). $50 \mathrm{mM} \mathrm{HEPES}, \mathrm{pH} 7.2,60^{\circ} \mathrm{C}, \mathrm{H}_{2}$ atm.

\section{${ }_{75}$ Proposed mechanism}

Gathering these experimental results allows us to reasonably postulate the following hypothesis. In $\mathrm{O}_{2}$-sensitive hydrogenases, $\mathrm{Ni}$-B was shown by FTIR to exhibit only a weak photosensitivity. However transition from the active Ni-SIa to the inactive Ni-B state is reached trough an inactive intermediate Ni-SIr known to be photosensitive ${ }^{34}$. In contrast, this transient $\mathrm{Ni}-\mathrm{SIr}$ state was not observed in $\mathrm{O}_{2-}$ tolerant hydrogenases using FTIR approaches, although not ruled out, most probably because much faster reactivation from the Ni-B to 80 the Ni-SIa state occurs ${ }^{8,24}$. We propose that irradiation of MbH1 under turnover conditions promotes the loss of the hydroxo ligand on the putative photo-induced Ni-SL state (Scheme 1). This is the first electrochemical evidence of such a photoreactivation occurring under turnover conditions. 


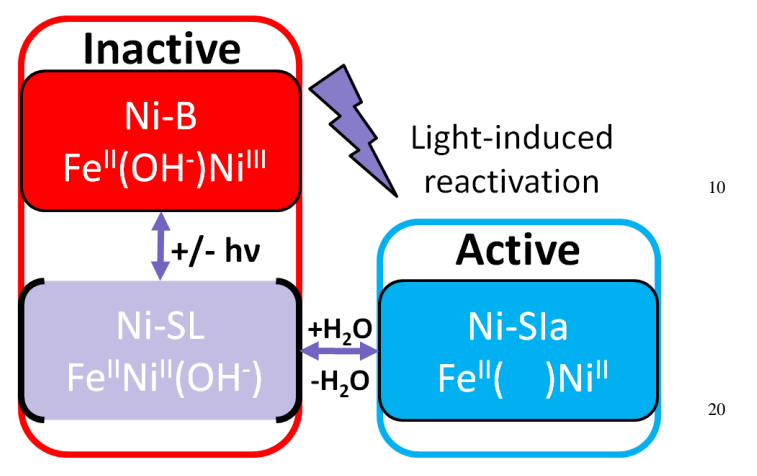

Scheme 1 Proposed mechanism for the light-induced reactivation process of MbH1 trough the putative Ni-SL redox state (between black brackets).

\section{Conclusions}

25 Based on electrochemical experiments under illumination, we have shown that: (i) illumination induces oxidative catalytic photocurrents, (ii) magnitude of photocurrents depends on applied potential, (iii) magnitude of photocurrents depends on light intensity, (iv) rate of photooxidation depends on potential, (v) rate of photooxidation depends on light intensity above $-0.3 \mathrm{~V}$. Evidence of a potential dependence of light-induced reactivation of $\mathrm{MbH} 1$ is thus demonstrated.

\section{Acknowledgments}

30 Financial support by Région Provence-Alpes-Côte d'Azur, and ANR Bioénergie. V. Marchi thanks the Direction Générale de l'Armement (DGA) for phD fellowship to C. Hamon. We thank Innovative Solutions for Instrumentation and Science [IS] ${ }^{2}$ for the light setup, contact@is2ws.com. We thank M. Bauzan for growing the bacteria.

\section{References}

35 1. E. Lojou, Electrochim. Acta., 2011, 56, 10385-10397.

2. P. M. Vignais and B. Billoud, Chem. Rev., 2007, 107, 4206-4272.

3. M. T. Stiebritz, A. R. Finkelmann and M. Reiher, Eur. J. Inorg. Chem., 2011, 1163-1171.

4. S. T. Stripp, G. Goldet, C. Brandmayr, O. Sanganas, K. A. Vincent, M. Haumann, F. A. Armstrong and T. Happe, Proc. Natl. Acad. Sci. U. S. A., 2009, 106, 17331-17336.

40 5. K. A. Vincent, A. Parkin, O. Lenz, S. P. J. Albracht, J. C. Fontecilla-Camps, R. Cammack, B. Friedrich and F. A. Armstrong, J. Am. Chem. Soc., 2005, 127, 18179-18189.

6. A. L. de Lacey, E. C. Hatchikian, A. Volbeda, M. Frey, J. C. Fontecilla-Camps and V. M. Fernandez, J. Am. Chem. Soc., 1997, 119, 7181.

7. C. Fichtner, C. Laurich, E. Bothe and W. Lubitz, Biochemistry, 2006, 45, 9706-9716.

8. M. E. Pandelia, V. Fourmond, P. Tron-Infossi, E. Lojou, P. Bertrand, C. Leger, M. T. Giudici-Orticoni and W. Lubitz, J. Am. Chem. Soc., 2010, 132, 6991-7004.

9. H. S. Shafaat, O. Rüdiger, H. Ogata and W. Lubitz, Biochim. Biophys. Acta. 2013 Feb 8. pii: S0005-2728(13)00025-X. doi: 10.1016/j.bbabio.2013.01.015., 2013.

10. W. Lubitz, M. Brecht, S. Foerster, M. van Gastel and M. Stein, in Paramagnetic Resonance Of Metallobiomolecules, Amer Chemical Soc, Washington, 2003, vol. 858, pp. 128-149.

50 11. C. Leger, S. Dementin, P. Bertrand, M. Rousset and B. Guigliarelli, J. Am. Chem. Soc., 2004, 126, $12162-12172$.

12. M. van Gastel, C. Fichtner, F. Neese and W. Lubitz, Biochem. Soc. Trans., 2005, 33, 7-11.

13. A. Volbeda, L. Martin, C. Cavazza, M. Matho, B. W. Faber, W. Roseboom, S. P. J. Albracht, E. Garcin, M. Rousset and J. C. Fontecilla-Camps, J. Biol. Inorg. Chem., 2005, 10, 239-249.

14. H. Ogata, S. Hirota, A. Nakahara, H. Komori, N. Shibata, T. Kato, K. Kano and Y. Higuchi, Structure, $2005,13,1635-1642$.

55 15. A. Abou Hamdan, B. Burlat, O. Gutierrez-Sanz, P. P. Liebgott, C. Baffert, A. L. De Lacey, M. Rousset, B. Guigliarelli, C. Leger and S. Dementin, Nat. Chem. Biol., 2013, 9, 15-18.

16. J. C. Fontecilla-Camps, A. Volbeda, C. Cavazza and Y. Nicolet, Chem. Rev., 2007, 107, 4273-4303.

17. J. Fritsch, O. Lenz and B. Friedrich, Nat. Rev. Microbiol., 2013, 11, 106-114.

18. A. Ciaccafava, P. Infossi, M. Ilbert, M. Guiral, S. Lecomte, M. T. Giudici-Orticoni and E. Lojou, Angew. Chem. Int. Edit., 2012 , 51, 953-956.

60 19. S. Frielingsdorf, T. Schubert, A. Pohlmann, O. Lenz and B. Friedrich, Biochemistry, 2011, 50, 10836-10843.

20. M. Guiral, P. Tron, V. Belle, C. Aubert, C. Léger, B. Guigliarelli and M. T. Giudici-Orticoni, Int. J. Hydrogen Energy, $2006,31,1424-1431$.

21. J. Y. H. Kim, B. H. Jo and H. J. Cha, J. Biotechnol., 2011, 155, 312-319.

22. M. J. Lukey, A. Parkin, M. M. Roessler, B. J. Murphy, J. Harmer, T. Palmer, F. Sargent and F. A. Armstrong, J. Biol. Chem., $2010,285,3928-3938$.

23. X. Luo, M. Brugna, P. Tron-Infossi, M. T. Giudici-Orticoni and E. Lojou, J. Biol. Inorg. Chem., 2009, 14, 1275-1288.

65 24. V. Fourmond, P. Infossi, M. T. Giudici-Orticoni, P. Bertrand and C. Leger, J Am Chem Soc, 2010, 132, 4848-4857.

25. J. Fritsch, P. Scheerer, S. Frielingsdorf, S. Kroschinsky, B. Friedrich, O. Lenz and C. M. Spahn, Nature, $2011,479,249-252$.

26. Y. Shomura, K. S. Yoon, H. Nishihara and Y. Higuchi, Nature, 2011, 479, 253-256.

27. A. Volbeda, P. Amara, C. Darnault, J. M. Mouesca, A. Parkin, M. M. Roessler, F. A. Armstrong and J. C. Fontecilla-Camps, Proc Natl Acad Sci U S A, 2012, 109, 5305-5310. 
28. M. E. Pandelia, W. Lubitz and W. Nitschke, Biochimi. Biophys. Acta., 2012, 1817, 1565-1575.

29. K. Grubel and P. L. Holland, Angew. Chem. Int. Edit., 2012, 51, 3308-3310.

30. A. Ciaccafava, A. De Poulpiquet, V. Techer, M. T. Giudici-Orticoni, S. Tingry, C. Innocent and E. Lojou, Electrochem. Commun., 2012, 23, 25-28.

31. S. Krishnan and F. A. Armstrong, Chem. Sci., 2012, 3, 1015-1023.

5 32. L. Xu and F. A. Armstrong, Energy Environ. Sci., 2013, 6, 2166-2171

33. H. Osuka, Y. Shomura, H. Komori, N. Shibata, S. Nagao, Y. Higuchi and S. Hirota, Biochem. Biophys. Res. Commun., $2013,430,284-288$.

34. M. E. Pandelia, H. Ogata, L. J. Currell, M. Flores and W. Lubitz, J. Biol. Inorg. Chem., 2009, 14, $1227-1241$.

35. M. E. Pandelia, P. Infossi, M. T. Giudici-Orticoni and W. Lubitz, Biochemistry, 2010, 49, 8873-8881.

36. M. E. Pandelia, H. Ogata, L. J. Currell, M. Flores and W. Lubitz, Biochim. Biophys. Acta., 2009 , 1797, 304-313. 